Gut, 1973, 14, 491-501

\title{
Immunochemical study of the malabsorption syndrome with cow's milk intolerance
}

\author{
E. SAVILAHTI ${ }^{1}$ \\ From the Children's Hospital, University of Helsinki, Finland
}

SUMmARY The effect of cow's milk provocation on the immunoglobulins in the intestinal mucosa, intestinal juice, stool extracts, as well as on the levels of antibodies to cow's milk and beta-1C/A in serum, was studied in 18 infants with the malabsorption syndrome. The infants improved on breast milk and were therefore suspected to be intolerant to cow's milk and challenged with it.

At the time of clinical relapse a marked and uniform increase in the numbers of IgA- and IgMcontaining cells, $2 \cdot 4$ times as many on the average as before challenge, was observed in the jejunal mucosa of eight reacting patients at nine provocations with cow's milk. There was no abnormality in the immunoglobulin-containing cells before challenge or in biopsy specimens taken shortly after the resumption of the elimination diet (breast milk). The clinical reaction was preceded by a pronounced rise in the IgA and IgM contents of stool extracts, and a rise in the titre of haemagglutinating antibodies and serum IgA, changes which subsided rapidly after withdrawal of cow's milk. There was no evidence that the reaction was IgE-mediated or complement-consuming.

In some of the 10 patients who tolerated cow's milk challenge clinically there was an increase in both IgA- and IgM-containing cells suggestive of a local immunological reaction although no clinical intolerance was provoked and other immunological signs were weak or absent. In other non-reacting patients no immunological reaction was noted. Therefore it is evident that cow's milk is the agent responsible for the strong local intestinal reaction coinciding with the clinical symptoms.

A syndrome consisting of failure to thrive, vomiting, diarrhoea, malabsorption, and damage to the jejunal mucosa has been recognized in young infants, many of whom have never received gluten (Davidson, Burnstein, Kugler, and Bauer, 1965; Fällström, Winberg, and Andersen, 1965; Kuitunen, 1966; Visakorpi and Immonen, 1967; Liu, Tsao, Moore, and Giday, 1967; Silver and Douglas, 1968). It has been demonstrated earlier that most of these patients are intolerant to cow's milk and especially to its proteins (Davidson et al, 1965; Visakorpi and Immonen, 1967; Liu et al, 1968). When cow's milk is excluded from the diet clinical improvement takes place, as well as normalization of the damaged intestinal mucosa at both light and electron microscopic level (Kuitunen, 1966; Kuitunen, Rapola, Savilahti, and Visakorpi, 1972). Provocation with cow's milk in these patients results in symptoms after some hours or slow deterioration of the clinical

'Address: Children's Hospital, Stenbäckinkatu 11, 00290 Helsinki 29, Finland.

Received for publication 2 March 1973. condition even weeks after the start of the challenge, and simultaneously by morphological damage of the jejunal mucosa reappears (Kuitunen et al, 1972; Jos, Rey, and Frézal, 1972). In contrast to coeliac disease, which is a permanent intolerance to gluten, intolerance to cow's milk vanishes with age (Davidson et al, 1965; Visakorpi and Immonen, 1967; Silver and Douglas, 1968).

Earlier observations of immunological changes, such as elevated serum IgA and precipitins to cow's milk (Immonen, 1967) in this syndrome, suggested that a study of the local immunoglobulin-producing system of the gut would throw light on the pathogenesis. This study was performed during cow's milk challenges on infants with the malabsorption syndrome, in whom intolerance to cow's milk was suspected, because they showed improvement on an elimination diet of breast milk. During these challenges the patients fell into two groups: some showed a clinical reaction to the provocation, while others tolerated cow's milk clinically. This local immunoglobulin production was estimated by measuring numbers of immunoglobulin-containing cells in biopsy specimens 


\begin{tabular}{|c|c|c|}
\hline & Group $I^{1}$ & Group II \\
\hline $\begin{array}{l}\text { Number of patients } \\
\text { Sex ratio (male/female) } \\
\text { Age on admission to hospital } \\
\text { Mean and range in days } \\
\text { Duration of elimination diet before challenge with cow's milk } \\
\text { Mean and range in days } \\
\text { Age at the beginning of challenge with cow's milk (age at the pre-challenge biopsy) } \\
\text { Mean and range in days } \\
\text { Duration of challenge (interval to the post-challenge biopsy) } \\
\text { Mean and range in days } \\
\text { Duration of renewed elimination diet (interval to the biopsy on the renewed elimination diet) } \\
\text { Mean and range in days }\end{array}$ & $\begin{array}{l}\quad 8 \\
3 / 8 \\
84 \\
47-151 \\
72 \\
26-172 \\
170 \\
92-219 \\
24 \\
1-42 \\
27 \\
10-45\end{array}$ & $\begin{array}{l}10 \\
5 / 5 \\
94 \\
28-200 \\
64 \\
25-120 \\
168 \\
65-247 \\
29 \\
14-42 \\
- \\
-\end{array}$ \\
\hline
\end{tabular}

Table I Clinical data for patients with the malabsorption syndrome with suspected intolerance to cow's milk

${ }^{1}$ Group I, patients who showed clinical symptoms on cow's milk; group II, patients who tolerated cow's milk.

${ }^{2}$ Every challenge was stopped immediately if the patient showed symptoms of a clinical relapse.

taken at the time when morphological evidence of the effect of the dietary treatment was needed. In addition, serial serum and faecal samples were studied for their content of immunoglobulins, and the serum levels of beta-1C/A and antibodies to cow's milk were followed during cow's milk provocation.

\section{Patients}

The series consisted of 18 patients (table I) admitted to hospital because of gastrointestinal symptoms, such as vomiting, prolonged diarrhoea, dehydration, and failure to thrive. All had received food con- taining cow's milk before the onset of symptoms and seven of the patients had also eaten gluten. In all cases malabsorption was verified either by abnormal faecal fat excretion or abnormal D-xylose excretion or both (table II). All but one had abnormal jejunal mucosa initially or/and after challenge with cow's milk. Owing to the poor condition of many of the patients primary laboratory investigations are incomplete. Patients who had received gluten were first treated with a gluten-free diet, but without success. Institution of a breast milk diet had a favourable effect on either the clinical condition or the absorptive function or both in every case. Therefore the patients were suspected of having the mal-

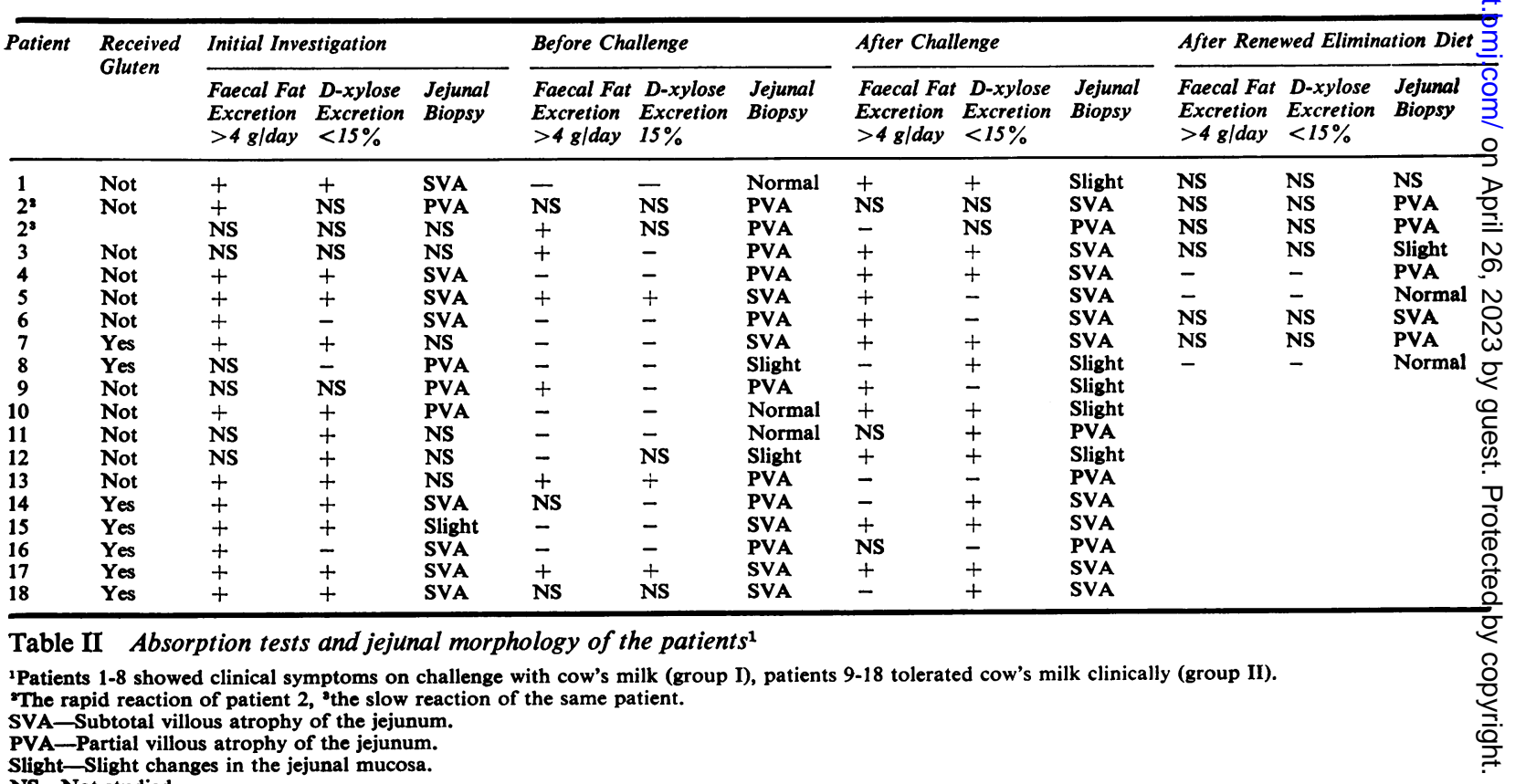


absorption syndrome with cow's milk intolerance and were challenged with it.

\section{Challenge}

After a variable period on breast milk diet (table I), the patients, when thriving, were exposed to a formula made up of unadapted powdered cow's milk. The challenge was started with a single dose of $5 \mathrm{ml}$ of the formula on the first day and if no reaction was noted the patient was transferred gradually to cow's milk formula alone in a period of one week. During the challenges the patients fell into two groups clinically. Eight (group I) reacted clinically to cow's milk. Every challenge was stopped immediately if any clinical signs attributive to the injurious effect of feeding cow's milk such as recurrent vomiting, and/or diarrhoea, and/or failure to gain weight, were noted. One of these patients showed a rapid reaction at the age of 3 months. Vomiting and diarrhoea appeared four hours after a single feed of formula. The other seven patients reacted slowly (table I), and three months later the patient with a rapid reaction exhibited a slow reaction, which was also investigated. Thus altogether nine reactions to cow's milk were followed. After a clinical reaction the elimination diet of breast milk was resumed and gradually changed, after a variable period (table I), to soy bean formula, on which these patients were discharged from hospital. Ten patients tolerated cow's milk clinically and were discharged after two to six weeks on a cow's milk feed (table I), and none of these had a later clinical relapse.

\section{Samples}

JEJUNAL BIOPSY SPECIMENS FOR

IMMUNOFLUORESCENT STUDY

Jejunal biopsy was performed in only two cases before the start of the elimination diet. Eleven other initial biopsies (table II) were taken, when the patient was already on a breast milk diet, but these were not used for immunofluorescent study. The biopsy specimens before provocation were obtained the day before the start of the challenge with cow's milk. The specimens after challenge (table I) were taken when the patients showed clinical symptoms, but were still on a cow's milk formula, and the biopsy on renewed elimination diet before they were transferred to the soy beam formula. The second biopsy of non-reacting patients was taken before discharge from hospital on a cow's milk formula. Specimens of six age-matched children without intestinal diseases (Savilahti, 1972a) served as controls. Biopsy specimens were taken with a Crosby-Kugler biopsy capsule, paediatric size, from the upper part of the jejunum. They were processed for direct immunofluorescent study as described earlier (Savilahti, 1972a).

INTESTINAL JUICE

Intestinal juice was taken from the lower part of the duodenum via the biopsy tubing. It was collected in a flask kept in ice and stored at $-20^{\circ} \mathrm{C}$ for a maximum period of three months before it was studied.

\section{SERUM SAMPLES}

A blood sample was taken immediately before the first cow's milk feed, and then one, three, six, 12 , and 24 hours after it. Blood was withdrawn daily during the first week on the cow's milk challenge and then twice a week. On the elimination diet blood samples were taken twice a week.

FAECAL SAMPLES

Faecal samples were taken on the same days as blood samples. A sample of a single stool was taken immediately after evacuation and stored for a maximum of two weeks at $-20^{\circ} \mathrm{C}$. Thawed samples were weighed and an equal amount of phosphatebuffered saline, $\mathrm{pH} 7 \cdot 2$, was added. The mixture was homogenized with an Ultra-Turrax for $2 \times 5$ seconds and centrifuged at $0^{\circ} \mathrm{C}$ for 15 minutes at $12000 \mathrm{~g}$. Measurements were made on the clear supernatants. A full series of serum and faecal samples was taken from 12 patients, while in the remaining cases fewer blood samples and no faecal samples were taken.

\section{Methods}

IMMUNOFLUORESCENT STUDY

Conditions for fluorescent microscopy and measuring cell numbers have been described earlier (Savilahti, 1972a and b). Cell densities were expressed as cells $/ \mathrm{mm}^{2}$.

IMMUNOGLOBULIN MEASUREMENTS

IgA, IgM, and IgG contents of serum and faecal extracts were measured by single radial immunodiffusion (Mancini, Carbonara, and Heremans, 1965), with the modifications of Immonen (1967). Intestinal juice levels of $\operatorname{IgA}$, IgM, and IgG were measured by electroimmunodiffusion (Lopez, Tsu, and Hyslop, 1969). Details of the antisera used in the immunofluorescent study and the measurements made have been described earlier (Savilahti, 1972a). Serum IgE was quantified by radioactive single radial immunodiffusion (Rowe, 1969) with modifications (Savilahti, 1973). A standard serum high in IgE was referred to the WHO research standard for human serum immunoglobulin E 68/341 (Rowe, Tackett, 
Bennich, Ishizaka, Johansson, and Anderson, 1970). The lower limit of sensitivity for IgE was $50 \mathrm{IU} / \mathrm{ml}$. Rabbit antiserum to human IgE was obtained from the Netherlands Red Cross.

BETA-1 C/A MEASUREMENT

Rabbit antiserum to human beta-AC/A was obtained from Behringwerke, Germany. Serum samples were kept at room temperature for 16 hours before diffusion and were measured by single radial immunodiffusion (Immonen, 1967). Standard human serum (Behringwerke, Germany) was used as reference in the measurements. The mean concentration of 61 healthy children was $80 \mathrm{mg} / 100 \mathrm{ml}$ (SD $12 \mathrm{mg} / 100 \mathrm{ml}$ ).

ANTIBODIES TO COW'S MILK

Precipitating antibodies to cow's milk were determined according to Heiner, Lahey, Wilson, Gerrard, Shwachman, and Khaw (1962). Haemagglutinating antibodies were titrated (Boyden, 1951) with 0 Rh-negative red blood corpuscles coated with dairy milk defatted by centrifugation for $\mathbf{3 0}$ minutes at $12000 \mathrm{~g}$. Twofold serial dilutions starting from 1:10 were studied. Serum from a rabbit immunized with milk similar to that used for coating was taken as a positive control. Titrations where the positive control was within \pm one tube of its median titre were accepted.

\section{Results}

IMMUNOGLOBULIN-CONTAINING CELLS IN THE JEJUNAL MUCOSA

In two specimens taken from reacting patients before the elimination diet, the numbers of IgA- and IgMcontaining cells were much higher than in the con- trols, but normalized on the elimination diet (figs 1 and 2). In all reacting patients the numbers of IgA- and IgM-containing cells were in the normal range at the start of the challenge. A clear rise in IgA-containing cells was seen in all patients, when they showed a clinical reaction to cow's milk irrespective of the length of the challenge (fig 1). An average of 2.4 times cells were seen as in the prechallenge counts (table III). During the renewed elimination diet the numbers of IgA-containing cells fell to the level seen before challenge in all these patients (fig 1). The rise of IgM-containing cells was as great as for $\operatorname{IgA}$ (fig 2), 2.4 times the numbers before challenge (table III), on average. On the renewed elimination diet their numbers fell in all but one (fig 2).

As in the controls, the numbers of IgG-containing cells were much lower than those of IgA- and IgMcontaining cells (table III) before challenge. The mean rise was also less than for IgA and IgM, 1.8 times the prechallenge numbers, and after withdrawal of cow's milk there was some fall in their numbers. The numbers of IgE-containing cells was followed in three reactions, one of which was rapid. In the rapid reaction and the other slow reaction no change in the number of IgE-containing cells was observed and they remained undetectable (below 3 cells/ $\mathrm{mm}^{2}$ ), while in the other slow reaction their numbers rose from 3 to 49 cells $/ \mathrm{mm}^{2}$, but they were still the rarest type of immunoglobulin-containing cells encountered in that specimen.

The effect of cow's milk challenge on the numbers of immunoglobulin-containing cells was less consistent in non-reacting patients (fig 3). More than 1.5 times the pre-challenge number of IgA-containing cells was seen in only five cases, but in the others the rise was slight and in two cases the numbers actually
$\mathbf{P}$

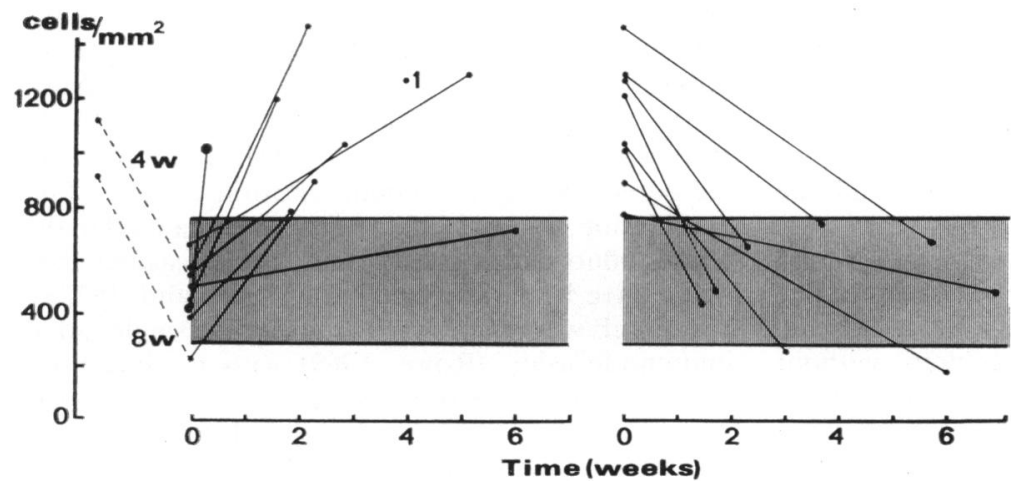

Fig 1 IgA-containing cells in reacting patients before and after a challenge with cow's milk, and after a renewed elimination diet (breast milk). Every challenge was stopped immediately, when the patient displayed symptoms of relapse. $P$, primary biopsies taken before any elimination diet. The interval to the pre-challenged biopsy is indicated in weeks (w). ${ }^{1}$ The biopsy before challenge was not studied. Shaded area, range of numbers of IgA-containing cells in six controls. 
$\mathbf{P}$

\section{CHALleNGE}

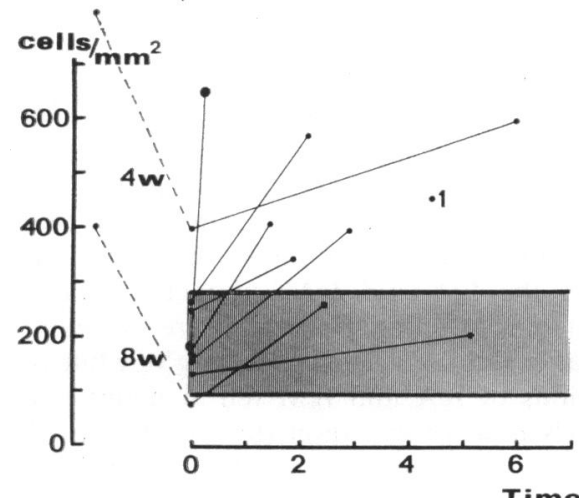

Time (weeks)

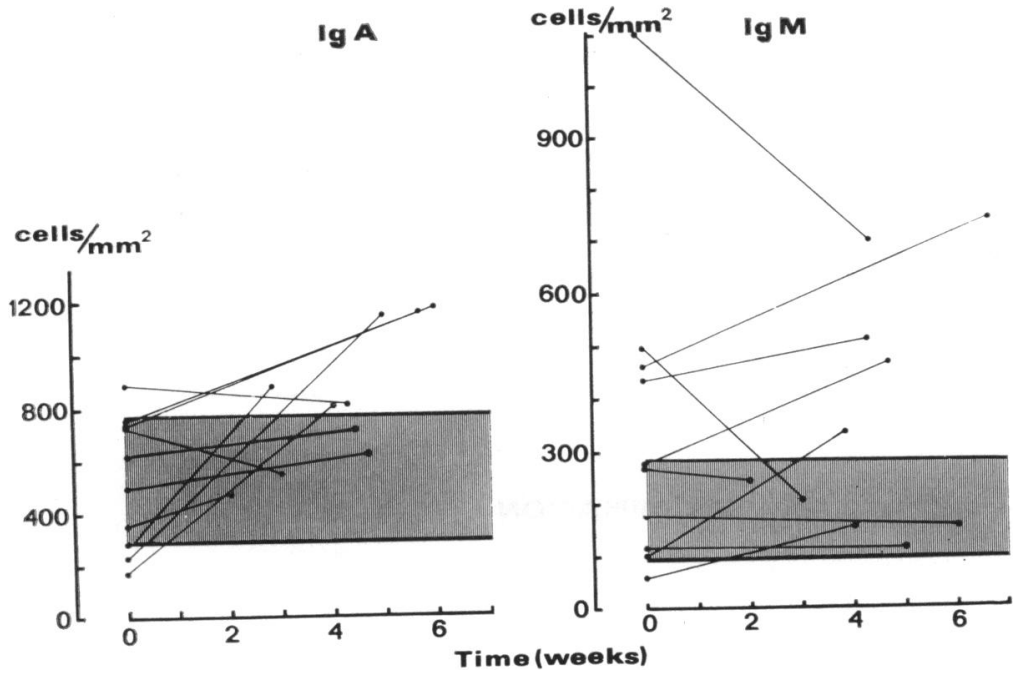

Fig 2 IgM-containing cells in reacting patients. Symbols as in figure 1.
Fig 3 IgA- and IgM-containing cells in non-reacting patients during cow's milk challenge. Symbols as in figure 1.

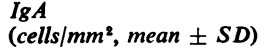

$\begin{aligned} 477 & \pm 133 \\ 1081 & \pm 252 \\ 440 & \pm 212 \\ & \\ 548 & \pm 272 \\ 852 & \pm 240 \\ 578 & \pm 171\end{aligned}$

IgM

$\left(\right.$ cells $/ \mathrm{mm}^{2}$, mean $\left.\pm S D\right)$

IgG

(cells/mm², mean $\pm S D)$

\section{Group I}

Before challenge

After challenge

After renewed elimination

Group $I^{2}$

Before challenge

After challenge

Controls

$\begin{array}{rr}205 \pm 98 & 56 \pm 16 \\ 441 \pm 151 & 98 \pm 42 \\ 241 \pm 92 & 80 \pm 33 \\ & \\ 350 \pm 307 & 110 \pm 63 \\ 363 \pm 229 & 107 \pm 63 \\ 192 \pm 70 & 80 \pm 35\end{array}$

Table III Immunoglobulin-containing cells in the jejunal mucosa of patients

${ }^{1}$ Group I, patients who showed clinical symptoms of cow's milk challenge.

'Group II, patients, who clinically tolerated cow's milk. 
fell (fig 3). Alterations in numbers were less regular in IgM-containing cells than in IgA-containing cells. In four of the five patients with elevation of IgAcontaining cells, the numbers of IgM-containing cells also increased. In five cases reduction of IgMcontaining cells was seen, all of which were in patients in whom IgA-containing cells either fell or were unchanged during challenge. The numbers of IgG-containing cells did not alter during provocation (table III). The numbers of IgE-containing cells were followed in five patients; the changes were inconsistent, with either small rises or diminutions.

\section{IMMUNOGLOBULINS IN THE INTESTINAL}

JUICE

Eight out of nine clinical reactions responded to challenge with a rise in $\operatorname{IgA}$, although the variation was great (table IV), and in seven of these IgM also rose. In these patients some reduction in the mean concentrations of $\operatorname{Ig} A$ and $\operatorname{IgM}$ was seen after withdrawal of cow's milk. Increases in the $\operatorname{IgA}$ content were of the same magnitude in the nonreacting patients as in the reacting ones, but for
IgM somewhat less. In only one of the 27 samples from the patients was IgG present in detectable quantities (above $0.9 \mathrm{mg} / 100 \mathrm{ml}$ ).

\section{IMMUNOGLOBULINS IN FAECAL EXTRACTS}

Without exception a pronounced rise in faecal IgA and IgM contents was noted one to five weeks before the patients showed clinical symptoms (figs 4 and 5). There was a rapid fall in the concentrations of these immunoglobulins after withdrawal of cow's milk. Changes in the IgA and IgM contents in faecal extracts of non-reacting patients were irregular; only one patient showed a clear rise in IgM, while the concentrations of $\operatorname{IgA}$ and $\operatorname{IgM}$ fell in many cases during cow's milk provocation (fig 6). Only a few faecal extracts contained measurable quantities of IgG.

SERUM IMMUNOGLOBULINS AND BETA-1C/A LEVELS

In six of the patients who showed a clinical reaction there was a marked rise in serum IgA level during provocation (fig 7 ). The rise in these cases usually

\begin{tabular}{|c|c|c|c|c|}
\hline & & $\begin{array}{l}\text { Before Challenge } \\
(m g / 100 \mathrm{ml}, \text { mean } \pm S D)\end{array}$ & $\begin{array}{l}\text { After Challenge } \\
(\mathrm{mg} / 100 \mathrm{ml}, \text { mean } \pm S D)\end{array}$ & $\begin{array}{l}\text { After Renewed Elimination Diet } \\
(\mathrm{mg} / 100 \mathrm{ml} \text {, mean } \pm S D)\end{array}$ \\
\hline Group I & $\begin{array}{l}\text { IgA } \\
\text { IgM }\end{array}$ & $\begin{array}{l}2.1 \pm 0.7 \\
1.3 \pm 1.4\end{array}$ & $\begin{array}{l}4.1 \pm 2.7 \\
3.9 \pm 3.4\end{array}$ & $\begin{array}{l}3 \cdot 7 \pm 2 \cdot 9 \\
3 \cdot 2 \pm 2 \cdot 0\end{array}$ \\
\hline Group II & $\begin{array}{l}\text { IgA } \\
\text { IgM }\end{array}$ & $\begin{array}{l}1.8 \pm 0.8 \\
2.0 \pm 1.5\end{array}$ & $\begin{array}{l}4 \cdot 1 \pm 2 \cdot 0 \\
2 \cdot 8 \pm 1 \cdot 8\end{array}$ & - \\
\hline Controls & $\begin{array}{l}\text { IgA } \\
\text { IgM }\end{array}$ & $\begin{array}{l}3.1 \pm 1.2 \\
4.8 \pm 3.9\end{array}$ & & \\
\hline
\end{tabular}

Table IV Immunoglobulins in the intestinal juice of patients

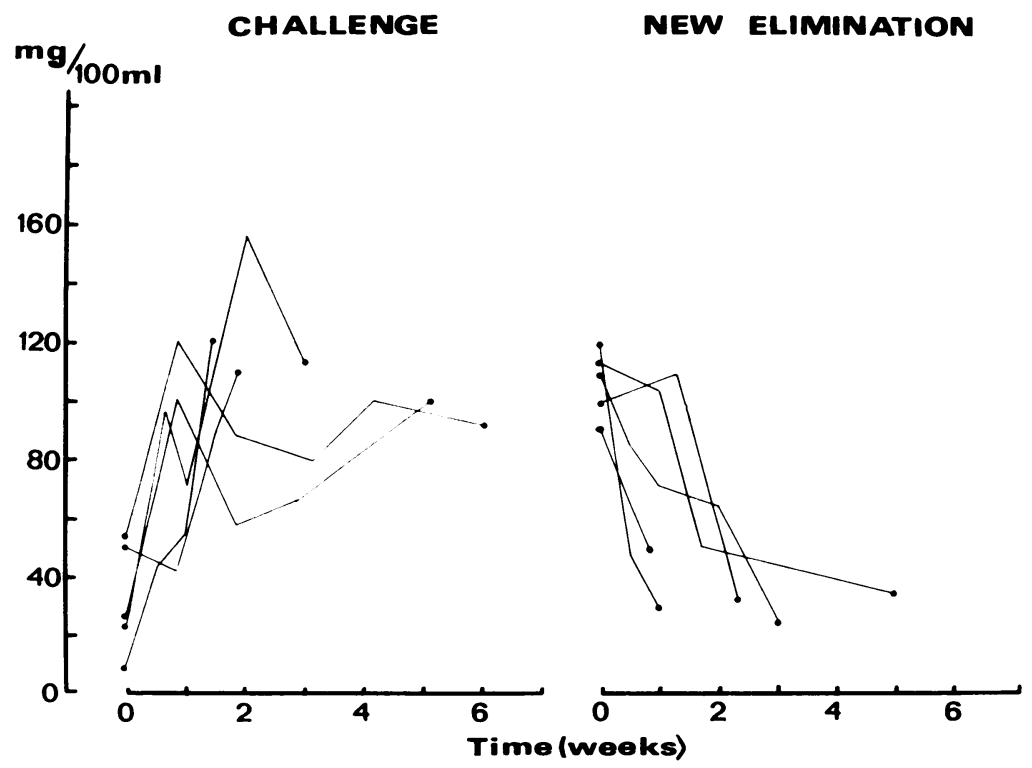

Fig 4 IgA content in faecal extracts of five reacting patients during cow's milk challenge and a renewed elimination (breast milk). 


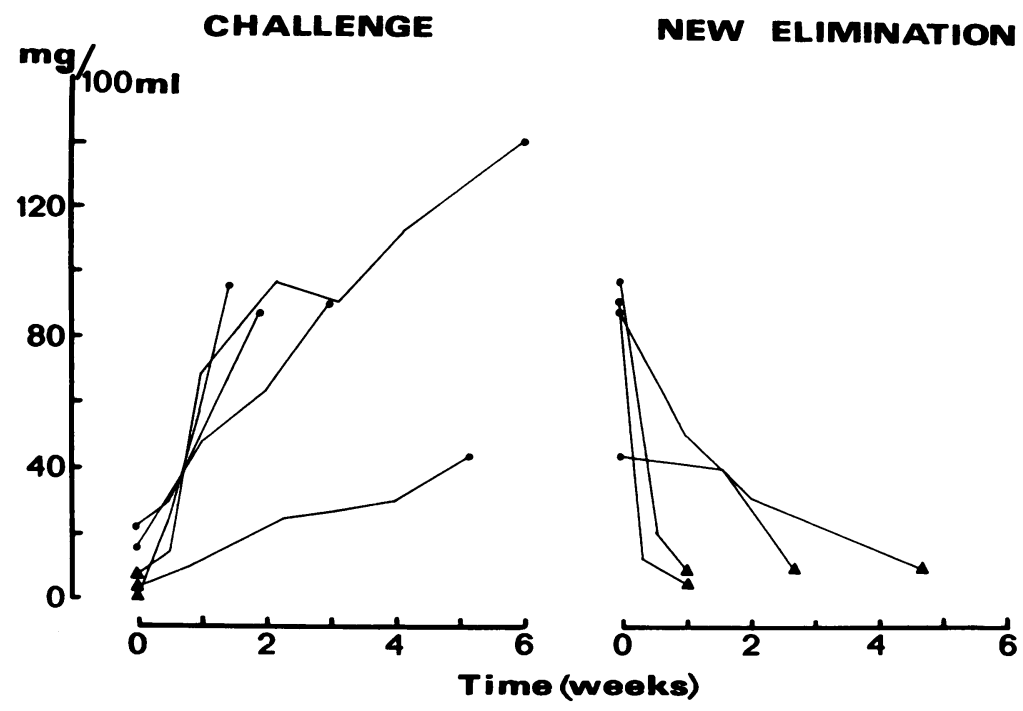

Fig 5 IgM content in faecal extract in reacting patients. $\Delta$-below the sensitivity of measurement $(<4 \mathrm{mg} / 100$ $m l)$.

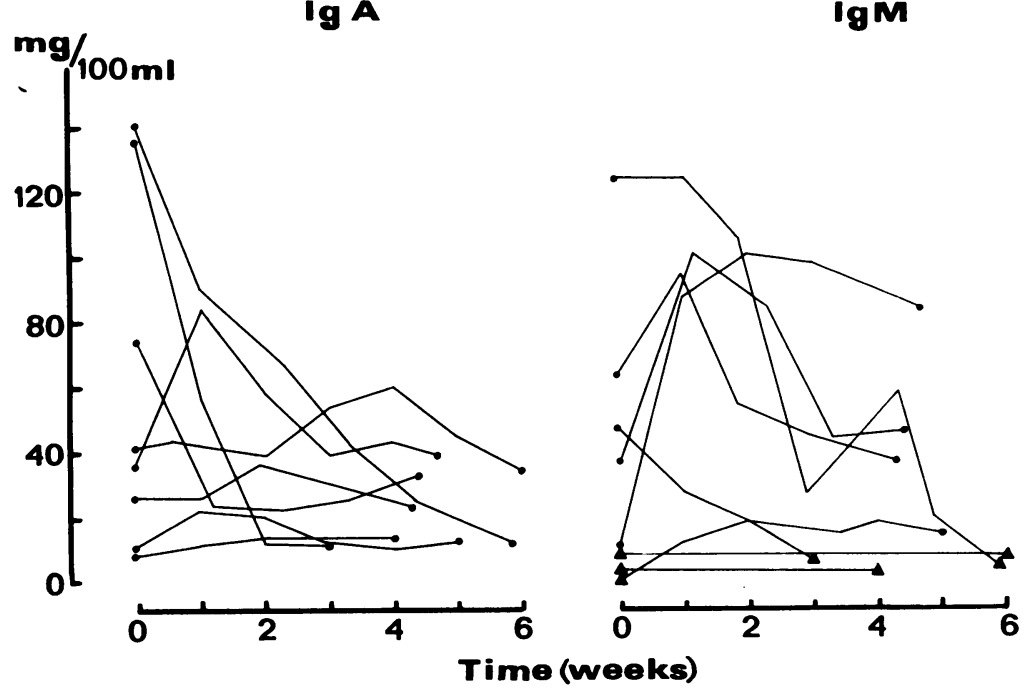

Fig 6 IgA and IgM contents in faecal extracts of eight non-reacting patients during cow's milk challenge. Symbols as in figure 5.

started one to four weeks before the appearance of clinical symptoms. IgA fell rapidly when the renewed elimination diet was started (fig 7). There was no constant change in serum IgM and IgG in reacting patients during cow's milk challenge. IgE levels in these patients were low $(50-150 \mathrm{IU} / \mathrm{ml})$ and no rise took place during provocation. Beta-1C/A levels remained stationary during cow's milk challenge $( \pm 20 \%$ of the pre-exposure value) in individual cases and were within the normal range (mean $\pm 2 \mathrm{SD}$ ). Even the rapid reaction in one patient did not cause any fall in beta-1C/A concentration in serial samples.
In non-reacting patients there were only two cases with a clear rise in serum IgA during cow's milk provocation (fig 8); in the others fluctuations were irregular. No changes were observed in the serum levels of IgM, IgG, IgE, or beta-1C/A in these patients during cow's milk challenge.

ANTIBODIES TO COW'S MILK

In the sera of all seven reacting patients followed the rise in the titre of haemagglutinating antibodies to cow's milk was eight times or more higher that of the pre-exposure titre (fig 9). The rise began one to five weeks before the appearance of clinical symptoms 


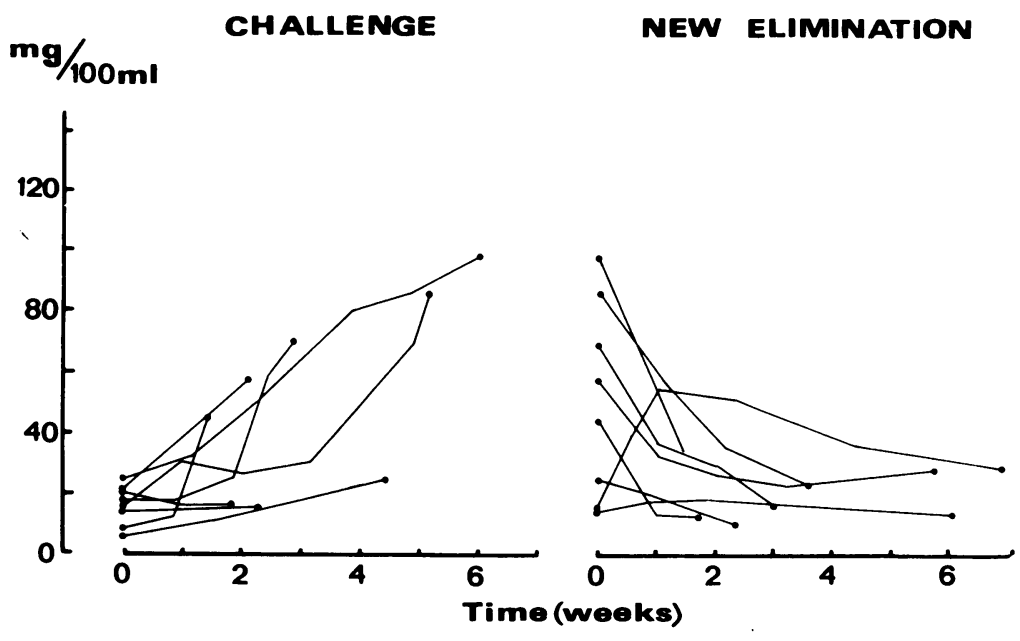

Fig 7 Serum IgA in eight patients with slow clinical reaction during challenge and on a renewed elimination diet.

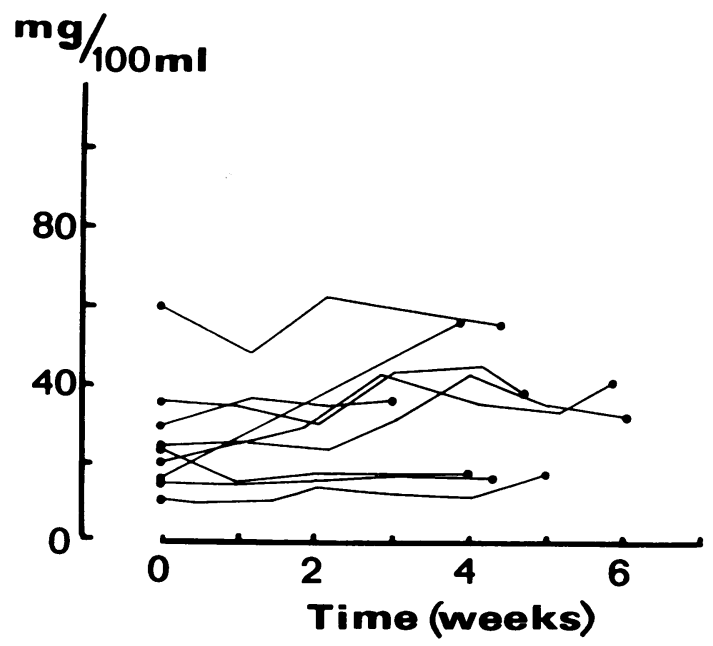

Fig 8 Serum $\operatorname{Ig} A$ in nine patients without clinical reaction during cow's milk challenge.

and the titre fell rapidly when cow's milk was eliminated. Changes in the precipitating antibodies were slower and persisted longer. In two cases precipitins were already present at the start of provocation. When absent, they appeared only shortly before the patient displayed symptoms or even after clinical symptoms were visible.

In eight of the non-reacting patients the changes in the titre of haemagglutinating antibodies were smaller; in only three of these cases was there an eight-fold increase in the titre of these antibodies (fig 10). Four of the non-reacting patients had precipitating antibodies to cow's milk at the start of the challenge, and in the sera of one of them they appeared during provocation, while in five cases no precipitins were seen before or after the provocation.

\section{Discussion}

The offending agent causing both the strong local immunological reaction in the intestinal mucosa and the clinical symptoms proved to be cow's milk. When this was excluded from the diet the numbers of immunoglobulin-containing cells fell to normal parallel with clinical improvement. Cow's milk provocation invariably caused an increase in the numbers of IgA- and IgM-containing cells if the challenge provoked clinical symptoms similar to those observed before the start of the elimination diet. Renewed elimination of cow's milk was again followed by normalization of cell numbers. Even in some patients who showed no clinical reaction to cow's milk there was an increase in the numbers of IgA- and IgM-containing cells after the challenge. As intolerance to cow's milk is known to disappear with age (Davidson et al, 1965; Visakorpi and Immonen, 1967; Silver and Douglas, 1968), it is possible that these patients had reached the phase at which they tolerated cow's milk clinically, but still exhibited an immunological reaction to it. In many non-reacting patients no change was seen in the numbers of immunoglobulin-containing cells after similar challenge with cow's milk. This argued against the possibility that secondary effects of cow's milk, such as a change in the intestinal microflora, were responsible for the strong local immunological reaction observed.

The study does not show which fraction of cow's milk causes the changes. Lactose cannot be incriminated, however, as the elimination diet used was 
challenge

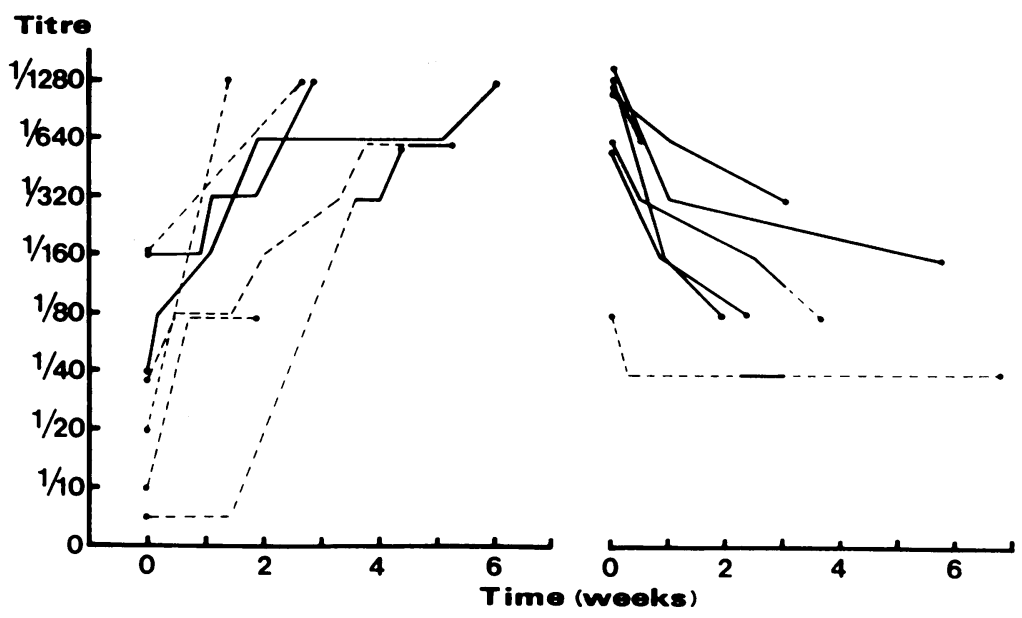

Fig 9 Antibodies to cow's milk in the sera of seven patients with slow reaction during challenge and on a renewed elimination diet. The lines represent the highest dilution of sera giving positive haemagglutination. Dotted line, precipitins to cow's milk were negative; continuing line, precipitins were positive.

\section{Challenge}

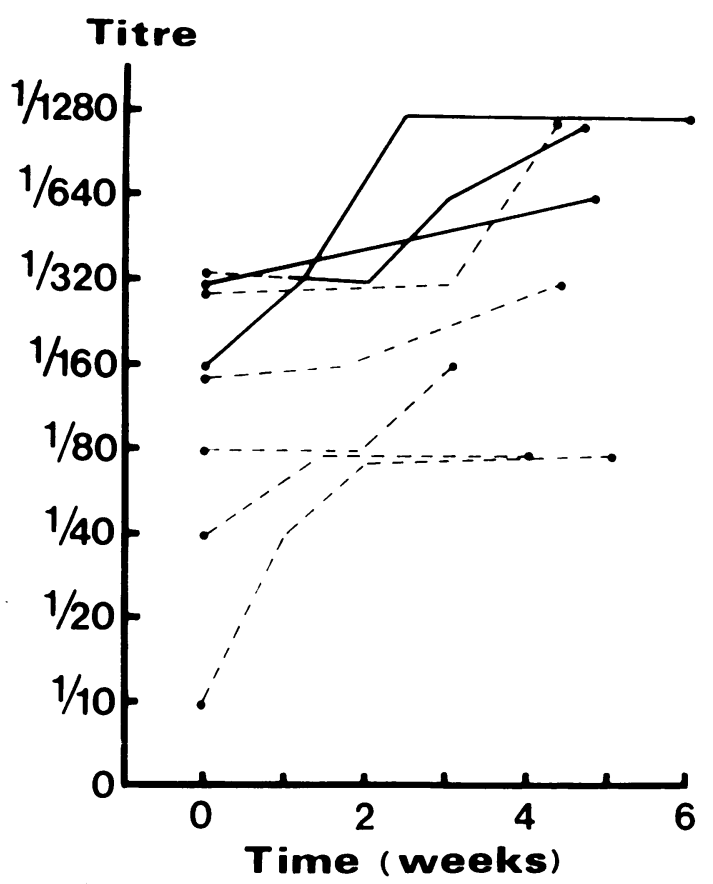

Fig 10 Antibodies to cow's milk in the sera of eight non-reacting patients. Symbols as in figure 9.

breast milk. Earlier clinical studies, in which separate protein fractions of cow's milk were used in provocations (Visakorpi and Immonen, 1967; Liu et al, 1967) suggested that one or more of them are the cause of the malabsorption syndrome. This view is supported by the finding in this study that, within hours of administration, a small dose of cow's milk caused clinical symptoms and a strong local immunological reaction in the intestine. It is evident that the agent that causes a rapid reaction to cow's milk is also responsible for the slow type of reaction, since the two types of reaction were seen in the same patient at different ages.

On the other hand, the increase of IgA and IgM was closely similar to that observed in children with untreated coeliac disease (Jos et al, 1972; Savilahti, 1972b). It can be speculated that just as the morphological response of the small intestine to a variety of noxious agents is the same, resulting in villous atrophy, the responses of the local immunoglobulin-producing system of the gut to such agents are similar. The increased production of IgA and IgM has also been shown in studies in vitro of biopsy specimens of coeliac patients after gluten challenge (Loeb, Strober, Falchuk, and Laster, 1971; Falchuk and Strober, 1972). Increase in the numbers of only IgA-containing cells was noted by Jos et al (1972) in seven untreated children with the malabsorption syndrome with cow's milk intolerance. However, at least some specimens in that study were taken after a short period of elimination diet, which may explain the discrepancy. In one child with clinical relapse IgM-containing cells, too, were increased (Jos et al, 1972).

This study does not fully clarify the importance of increased infiltration of IgA- and IgM-containing cells in the pathogenesis of the malabsorption syndrome with cow's milk intolerance. When the offending agent, cow's milk, is excluded from the diet, immunoglobulin-containing cells become normal as in coeliac patients after gluten withdrawal (Savilahti, 1972b) and in treated patients with the malabsorption syndrome with cow's milk intolerance (Jos 
et al, 1972). Therefore it is apparent that in this syndrome there is no primary abnormality in the immunoglobulin-producing system of the gut. The study suggests that the reaction is not IgE-mediated, as few if any IgE-containing cells were seen in the jejunal mucosa at the time of clinical reaction, and serum levels of IgE were stationary and low during the challenge. The study does not support the view (Matthews and Soothill, 1970) that the clinical reaction to cow's milk is complement consuming, as no decrease in the level of beta-1C/A was observed during the challenges, even when the reaction was rapid.

Changes in other immunological parameters in patients who show a clinical reaction are more or less reflections of the increased infiltration of $\operatorname{IgA}$ and IgM-containing cells in the jejunal mucosa. As the intestinal juice is a mixture of several secretions entering the gut lumen at variable velocity, it is not surprising that results of immunoglobulin measurements are not always correlated with the finding of cells in the intestinal mucosa. Measurement of immunoglobulins in faecal extracts indicated that excretion of $\operatorname{IgA}$ and IgM is much increased soon after the start of a challenge with cow's milk and long before a clinical reaction is apparent. No increases were noted in non-reacting patients. The observation bears a resemblance to the finding of increased production of $\operatorname{IgA}$ and $\operatorname{IgM}$ by biopsy specimens taken from coeliac patients soon after challenge with gluten (Loeb et al, 1971; Falchuk and Strober, 1972).

The challenge was later followed by elevation of serum IgA in reacting patients. The IgA is probably derived from the increased infiltration of $\operatorname{IgA}$ containing cells in the gut wall, as gut has been shown to be the major source of this immunoglobulin (Vaerman and Heremans, 1970; Bazin, Maldague, Schonne, Crabbé, Bauldon, and Heremans, 1971; Savilahti, 1972a). The increase in numbers of IgMcontaining cells was not reflected in the serum level of the patients. This is in accordance with observations on patients with IgA deficiency and with coeliac disease, who also have increased numbers of IgMcontaining cells and no elevation of serum IgM (Douglas, Crabbé, and Hobbs, 1970; Savilahti, 1972b; Savilahti, 1973).

The marked elevation of haemagglutinating antibodies to cow's milk may indicate increased permeability of the jejunal epithelium to cow's milk proteins in reacting patients. The observed increase is apparently a marker of intestinal damage, but not pathognomonic of intolerance to cow's milk, as such antibodies are also encountered in healthy children (Gunther, Aschaffenburg, Matthews, Parish, and Coombs, 1960; Kletter, Gery, Freier, and Davies,
1971). Much the same applies to precipitating antibodies, but there is a difference in their character, for changes in precipitins, though parallel to those in haemagglutinating antibodies, were slower. The clinical value of following faecal extract immunoglobulins, serum $\operatorname{IgA}$, and antibodies is the possibility to predict, fairly early during a challenge with cow's milk, which patient will later develop clinical symptoms.

The characteristic response of the local immunoglobulin-producing system of the gut to challenge with cow's milk was a marked increase in the number of IgA- and IgM-containing cells in patients who displayed clinical symptoms. This system showed no quantitative abnormality when the offending agent was eliminated. Therefore if the malabsorption syndrome with cow's milk intolerance is based on the immunological immaturity of the patient, this defect in handling cow's milk is due to a qualitative abnormality of the local immunoglobulin-producing system or a detrimental delayed type of hypersensitivity.

This work has been supported by grants from the Sigrid Jusélius Foundation and the National Research Council for Medical Sciences, Finland.

\section{References}

Bazin, H., Maldague, P., Schonne, E., Crabbé, P. A., Bauldon, H., and Heremans, J. F. (1971). The metabolism of different immunoglobulin classes in irradiated mice. V. Contribution of the gut to serum IgA levels in normal and irradiated mice. Immunology, 20, 571-595.

Boyden, S. V. (1951). The adsorption of proteins on erythrocytes treated with tannic acid and subsequent hemagglutination by antiprotein sera. J. exp. Med., 93, 107-120.

Davidson, M., Burnstine, R. C., Kugler, M. M., and Bauer, C. H. (1965). Malabsorption defect induced by ingestion of beta lactoglobulin. J. Pediat., 66, 545-554.

Douglas, A. P., Crabbé, P. A., and Hobbs, J. R. (1970). Immunochemical studies of the serum, intestinal secretions and intestinal mucosa in patients with adult celiac disease and other forms of the celiac syndrome. Gastroenterology, 59, 414-425.

Falchuk, Z. M., and Strober, W. (1972). Increased jejunal immunoglobulin synthesis in patients with nontropical sprue as measured by a solid phase immunoadsorption technique. $J$. Lab. clin. Med., 79, 1004-1013.

Fällström, S. P., Winberg, J., and Andersen, H. J. (1965). Cow's milk induced malabsorption as a precursor of gluten intolerance. Acta paediat. scand., 54, 101-115.

Gunther, M., Aschaffenburg, R., Matthews, R. H., Parish, W. E., and Coombs, R. R. A. (1960). The level of antibodies to the proteins of cow's milk in the serum of normal human infants. Immunology, 3, 296-306.

Heiner, D. C., Lahey, M. E., Wilson, J. F., Gerrard, J. W., Shwachman, H., and Khaw, K-T. (1962). Precipitins to antigens of wheat and cow's milk in celiac disease. J. Pediat., 61, 813-830.

Immonen, P. (1967). Levels of the serum immunoglobulins $\gamma \mathbf{A}, \gamma \mathbf{G}$, and $\gamma \mathrm{M}$ in the malabsorption syndrome in children. Ann. Paediat. Fenn., 13, 115-153.

Jos, J., Rey, J., and Frézal, J. (1972). Etude immuno-histochimique de la muquese intestinale chez l'enfant. I. Les syndromes de malabsorption. Arch. franc. Pediat., 29, 681-698.

Kletter, B., Gery, I., Freier, S., and Davies, A. M. (1971). Immune responses of normal infants to cow milk. I. Antibody type and kinetics of production. Int. Arch. Allergy, 40, 656-666. 
Kuitunen, P. (1966). Duodeno-jejunal histology in malabsorption syndrome in infants. Ann. Paediat. Fenn., 12, 101-132.

Kuitunen, P., Rapola, J., Savilahti, E., and Visakorpi, J. K. (1972). Light and electronmicroscopic changes in the small intestinal mucosa in patients with cow's milk induced malabsorption syndrome. Acta paediat. scand., 61, 237-238.

Liu-H-Y., Tsao, M. U., Moore, B., and Giday, Z. (1967). Bovine milk protein induced intestinal malabsorption of lactose and fat in infants. Gastroenterology, 54, 27-34.

Loeb, P. M., Strober, W., Falchuk, Z. M., and Laster, L. (1971). Incorporation of $\mathrm{L}$-leucine-14 $\mathrm{C}$ into immunoglobulins by jejunal biopsies of patients with celiac sprue and other gastrointestinal diseases. J. clin. Invest., 50, 559-569.

Lopez, M., Tsu, T., and Hyslop, N. E., Jr. (1969). Studies of electroimmunodiffusion: immunochemical quantitation of proteins in dilute solutions. Immunochemistry, 6, 513-526.

Mancini, G., Carbonara, A. O., and Heremans, J. F. (1965). Immunochemical quantitation of antigens by single radial immunodiffusion. Immunochemistry, 2, 235-254.

Matthews, T. S., and Soothill, J. F. (1970). Complement activation after milk feeding in children with cow's milk allergy. Lancet, 11, 893-895.
Rowe, D. S. (1969), Radioactive single radial diffusion: a method for increasing the sensitivity of immunochemical quantification of proteins in agar gel. Bull. Wld Hlth Org., 40, 613-616.

Rowe, D. S., Tackett, L., Bennich, H., Ishizaka, K., Johansson, S. G. O., and Anderson, S. G. (1970). A research standard for human serum immunoglobulin E. Bull. Wld Hlth Org., 43, 609-611.

Savilahti, E. (1972a). Immunoglobulin-containing cells in the intestina mucosa and immunoglobulins in the intestinal juice in children. Clin. exp. Immunol., 11, 415-425.

Savilahti, E. (1972b). Intestinal immunoglobulins in children with coeliac disease. Gut, 13, 958-964.

Savilahti, E. (1973). IgA deficiency in children. Immunoglobulincontaining cells in the intestinal mucosa, immunoglobulins in secretions and serum IgA levels. Clin. exp. Immunol., 13, 395-406.

Silver, H., and Douglas, D. M. (1968). Milk intolerance in infancy. Arch. Dis. Childh., 43, 17-22.

Vaerman, J. P., and Heremans, J. F. (1970). Origin and molecular size of immunoglobulin-A in the mesenteric lymph of the dog. Immunology, 18, 27-38.

Visakorpi, J. K., and Immonen, P. (1967). Intolerance to cow's milk and wheat gluten in the primary malabsorption syndrome in infancy. Acta paediat. scand., 56, 49-56. 